Sitzungsber. Abt. I (2006) 212: 3-18

Sitzungsberichte

Mathematisch-naturwissenschaftliche Klasse Abt. I

Biologische Wissenschaften und Erdwissenschaften

(c) Österreichische Akademie der Wissenschaften 2007

Printed in Austria

\title{
Altitudinal Variation in Flowering Time of Lilac (Syringa vulgaris L.) in the Alps in Relation to Temperatures
}

\author{
By \\ Walter Larcher \\ (Vorgelegt in der Sitzung der math.-nat. Klasse am 14. Dezember 2006 \\ durch das w. M. Walter Larcher)
}

\begin{abstract}
The flowering time of lilac is a frequently used bioindicator for temperature driven developmental processes in spring time. In the present study the influence of altitude on the flowering dates of lilac was investigated for 24 sites in the Northern and Central Alps, and 10 sites in the Southern Alps. The onset of flowering dates in these areas of the Alps are closely related to the mean air temperatures in April. A temperature decrease by $1^{\circ} \mathrm{C}$ postpones the onset of flowering by 6.6 days. This results in a gradient of lilac flowering times of 4.2-4.6 days per $100 \mathrm{~m}$ in the Central Alps between 600 and $1500 \mathrm{~m}$ a.s.l. and a gradient of 3.7 days per $100 \mathrm{~m}$ a.s.l. in the Southern Alps between 90 and $1100 \mathrm{~m}$ a.s.l.

Over the 20th century a deviation from the mean onset of flowering dates of about \pm 12 days was seen due to climatic fluctuations in the Northern and Central Alps. On the Southern rim of the Alps the thermal conditions are most favourable for the development of lilac and therefore, there are no remarkable time shifts to be seen.
\end{abstract}

\section{Introduction}

Phenology, the science of the developmental changes in the course of a year, is becoming more and more important; especially in times when the changeability of the climate is strongly brought to people's attention. Developmental processes that respond to seasonal changes 
are the emergence of bud break, unfolding of leaves, onset of flowering and fruit ripening as well as leaf senescence. The evaluation of phenological dates provides valuable information about the average times of onset and the duration of different phenophases of characteristic species in a given area (ROSENKRANZ [29], SCHNELLE [30], LAUSCHER [17]).

Temperature and day length are the most important factors influencing the life cycle of plants. For trees and shrubs in the temperate Northern Hemisphere, spring temperatures play a decisive role (BORCHERT et al. [1]). Thus, spring phenology seems to be a promising indicator for the impact of climate warming (MENZEL and FABIAN [22], CHMIELEWSKI and RÖTZER [2]). However, the relationships between climatic factors and defined stages of development of certain indicator plants are still difficult to prove as too many factors overlap. Data have shown that correlations can only be seen for restricted areas with comparable climatic conditions (DEFILA and Clot [6]).

The flowering time of lilac serves as an excellent bioindicator for temperature-driven developmental processes. The lilac bloom marks peak the spring time and can be observed effortlessly. IHNE [10] in his early phenological European maps used this widespread ornamental shrub as a signal for the onset of spring. SCHWARTZ et al. [32] used species of the genus Syringa as indicators of spring in a model for the Northern Hemisphere. In long-term surveys LAUSCHER and SCHNELLE [19] found a correlation between the onset of lilac flowering and temperature. Lilac bloom data were also used by ROLLER [28] and $\mathrm{KOCH}[11,12]$ as an indicator for the altitudinal gradient of temperatures.

The following case study investigated the relationships between the altitudinal gradient of air temperatures and the impact of altitude on onset of flowering of lilac at latitudes between $48^{\circ}$ and $-46^{\circ} \mathrm{N}$.

\section{Materials and Methods}

\subsection{Acquisition of Data}

Phenological Data. The phenological data presented were mainly compiled by literature research (see Table 1 and Fig. 4) and were completed with my own observations in Innsbruck (2003-2006) and in Arco, north of Lake Garda (1995-2004). The survey in Arco was carried out in an Arboretum in cooperation with the Natural Science Museum of Trento as part of the "Italian Phenological Garden Network" (TISI et al. [33]). 
Phenological data series from various sites in the Northern and Central Alps in the Tyrol (Kufstein, Scharnitz, Telfs and Matrei in Osttirol) were taken from long-term observations (1951-1999) of the Central Institute for Meteorology and Geodynamics in Vienna (KOCH [13]). Furthermore, phenological data from Kufstein, Innsbruck, Landeck, Lienz, Matrei in Osttirol and St. Jakob in Defereggen from between 1946 and 1960 were also taken from the Central Institute for Meteorology and Geodynamics in Vienna (RoLLER [27]). The period between 1961 and 1973 is covered by annotations of 19 locations provided by a short term programme of a Phenological Observation Service in the Tyrol.

Earlier data series from sites in the Southern Alps between 1922 and 1961 were obtained from PFAFF [25], DALla FIOR [4, 5] and Minio [23]. The sites investigated were Bozen, Oberbozen and Eppan in Southern Tyrol, as well as Trento, Borgo (Val Sugana), Cles (Val di Sole), Tione (Giudicarie), Pieve di Ledro and Predazzo (Val di Fiemme) in Trentino. Some data covering the period before 1900 from the Tyrol and Trentino were taken from lists of DALLA TORRE in FICKER [8]. I visited all the sites.

Climate Data. Air temperature data were taken from recordings carried out by various weather services. For sites in the Northern and Central Alps these data were obtained from the Central Institute for Meteorology and Geodynamics in Vienna (www.ZAMG.ac.at) and from the Hydrographical Service in Austria. Older time series were taken from FICKER [8] and REITER [26]. Temperature recordings for the Southern Alps were researched on the Internet; for Southern Tyrol at www.provinz.bz.it/wetter (Hydrographical Service, Province Bozen) and for Trentino at www.ismaa.it (Istituto Agrario San Michele all'Adige). The climate data for Arco were obtained from a local weather station (LARCHER [16] and own data until 2004).

\subsection{Processing of Data}

The onset dates of characteristic phenological phases were established from the observations and were recorded as day of the year. These data are to be seen as means, which can vary by at least $\pm 2-3$ days as the observations were not carried out on a daily basis.

Onset of Flowering. The onset of lilac flowering is officially defined by the German Weather Service as the time when "the lowest blossoms on numerous panicles of the lilac shrub start opening" (DEUTSCHER WETTERDIENST [7, p. 13]). The phenological Observa- 
tion Service for the Tyrol also gives a day of the year for the onset of lilac flowering. The phenological observers in the Southern Alps also use the same methodology (DALLA FIOR [3]: "inizio dell'antesi"; MARCELLO [20]: "boccioli rigonfi e fiori aperti").

Phenological Calculations. Means, standard deviations, medians and percentiles were calculated from the long-term data taken from publications by KоCH [13] to give. In the case of all the other data only means and some standard deviations were calculated. The relationship between flowering dates and temperatures was identified by correlation analysis (Statistical package SPSS Inc., Chicago, USA).

To calculate the relationships between phenological information and temperature, the same periods had to be used. During the phenological observation period considerable temperature fluctuations took place (Fig. 1). A series of air temperature data from Innsbruck (115 years) shows colder periods before 1900, between 1935 and 1941 and between 1954 and 1987; warmer periods were registered between 1911 and 1934 as well as in the years between 1943 and 1951, with a strong warming after 1988. The warmest year of the 20th century was 1994. It is remarkable that the spring temperature means do not

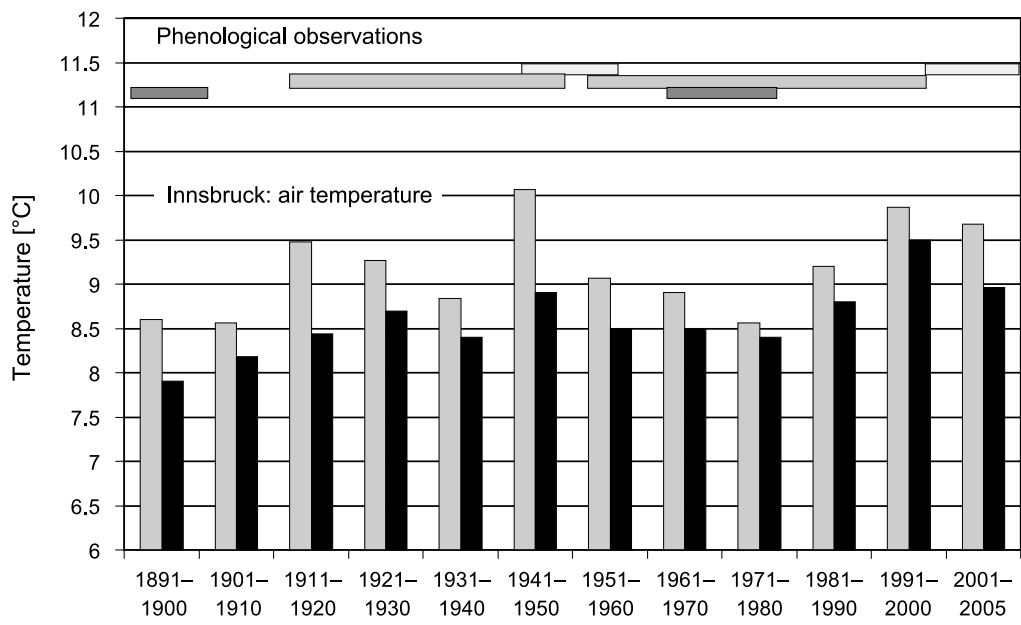

Fig. 1. Phenological observation periods and air temperatures in Innsbruck. Bars: phenological data from 1889-1900 (DALLA TORRE in FICKER [8]), 1910-1950 (data from Southern Tyrol and Trentino, see text), 1946-1960 (RoLLER [27]), 1951-1999 (КоCH [13]), 1961-1973 (Phenological Observation Service for Northern and Eastern Tyrol). Long-term data series of air temperature in Innsbruck: black columns: annual means, gray columns: spring means (March, April and May). The annual mean for the 115 -year study period was $8.6^{\circ} \mathrm{C}$ and the spring mean $9.2^{\circ} \mathrm{C}$ 
always match the annual means. This was especially striking in the decades between 1911-1930 and 1943-1951 with the warmest spring temperatures in 1946 and 1947. A similar trend could be seen for the Southern Alps (Bozen: warm periods 1926-1930 and 1941-1960).

\section{Results}

\subsection{The Sequence of Phenophases of Lilac}

During the course of a year plants undergo a series of developmental phases: Towards the end of the summer next year's buds are formed in the axils of the leaves; flower buds of lilac start differentiating as early as July (Fig. 2). Before leaves are shed the buds are rendered dormant by hormones, which prevent them from opening before the onset of winter. The termination of dormancy depends on the fulfilment of certain chilling requirements. In most cases, dormancy can only end after exposure to lower temperatures of about $6-8^{\circ} \mathrm{C}$ for a number of weeks. For lilac the cold requirement is usually fulfilled by the end of November (SCHÜEPP [31]). After that, lilac twigs flower after being exposed to warm water and a room temperature of 15$18^{\circ} \mathrm{C}$ (MoLisCH [24, p. 202]).

In the temperate climate zone the timing of bud break and flowering mostly depends on passing a certain temperature threshold. When the threshold is passed, elongation growth of the inflorescence axis is set off. Right after bud break the growth is rather slow. Only after sufficient temperature input is the programmed and quicker elongation growth achieved. So for elongation growth it is necessary
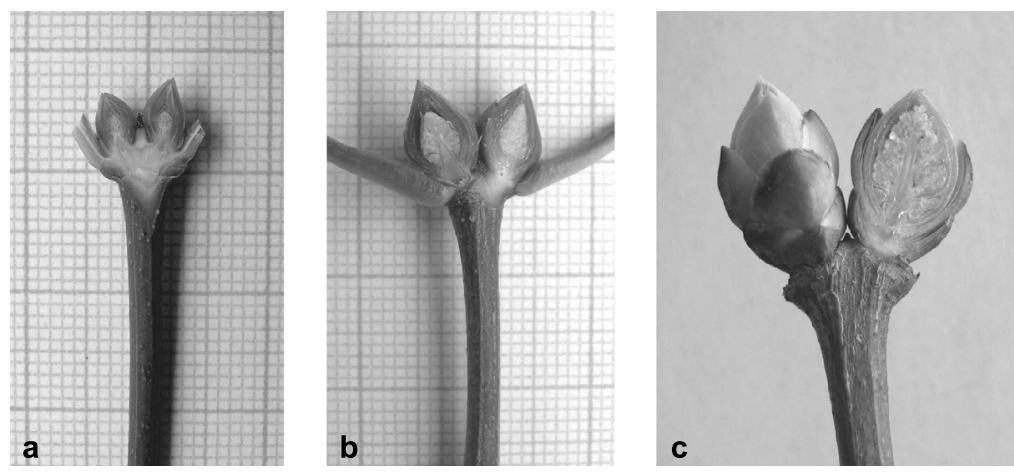

Fig. 2. Flower buds of lilac: (a) mid-July in the year before blooming; (b) midSeptember; (c) before bud break in end of March of the current year 

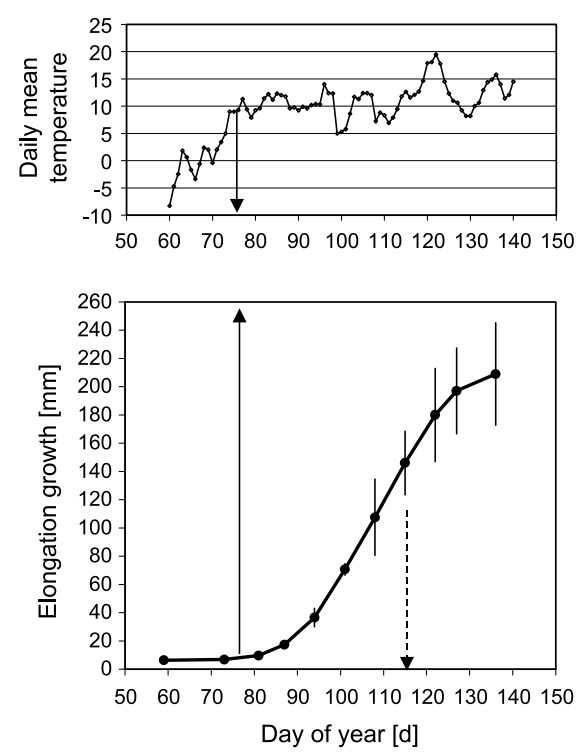

Fig. 3. Sprouting of flower buds and growth of inflorescences of Syringa vulgaris, and daily means of air temperature in Innsbruck between March 1 and May 20, 2005. The lilac hedge is located $2 \mathrm{~km}$ from the weather service's meteorological station. Error bars: standard deviation $(n=30)$. Left arrows: first day of bud break. Right arrow: onset of flowering. The data show a typically sigmoid course as the growth starts off slowly, gets faster in the linear elongation phase and ceases after having reached the maximum. During the phase of elongation growth daily means of about $5-10^{\circ} \mathrm{C}$ were predominant. At the onset of flowering daily mean temperatures in Innsbruck were higher than $10^{\circ} \mathrm{C}$

that a certain temperature threshold is passed to start the flowering period and also that the plant is exposed to suitable temperatures over a certain period of time. The moment the first flowers of the panicle start flowering, growth of the inflorescence slows down. Fig. 3 shows that there was an interval of about 40 days between the first day of sprouting and the onset of flowering. The linear elongation phase from the start to the peak of flowering lasted about 50 days.

In Innsbruck lilac needs about 30-35 days from anthesis through peak flowering to the end of the flowering period; fruit maturity and capsule dehiscence start about 120-130 days after anthesis. Under optimal temperature conditions, such as those found in Arco on the southern rim of the Southern Alps, anthesis lasts about 25 days and fruit dehiscence is reached after 100-110 days. 


\subsection{Onset of Lilac Flowering at Higher Altitudes of Mountain Ranges}

Increasing altitude reduces the temperature and thus postpones the onset of spring. Dates for the onset of flowering of lilac at different locations are listed in Table 1 and Fig. 4. These phenological data show a gradient of 4.2-4.6 days per $100 \mathrm{~m}$ for the Central Alps between 600 and $1500 \mathrm{~m}$ a.s.l., and a gradient of 3.7 days per $100 \mathrm{~m}$ for the Southern Alps between 90 and $1100 \mathrm{~m}$ a.s.l.

Fig. 5 shows the shift in onset of flowering dates with elevation in the different areas of the north-south-transect. In comparison to the Central Alps, the onset dates at all altitudes on the northern rim of the Alps are delayed and the onset dates in the Southern Alps are earlier. A shift towards a higher day number indicates a dominant influence

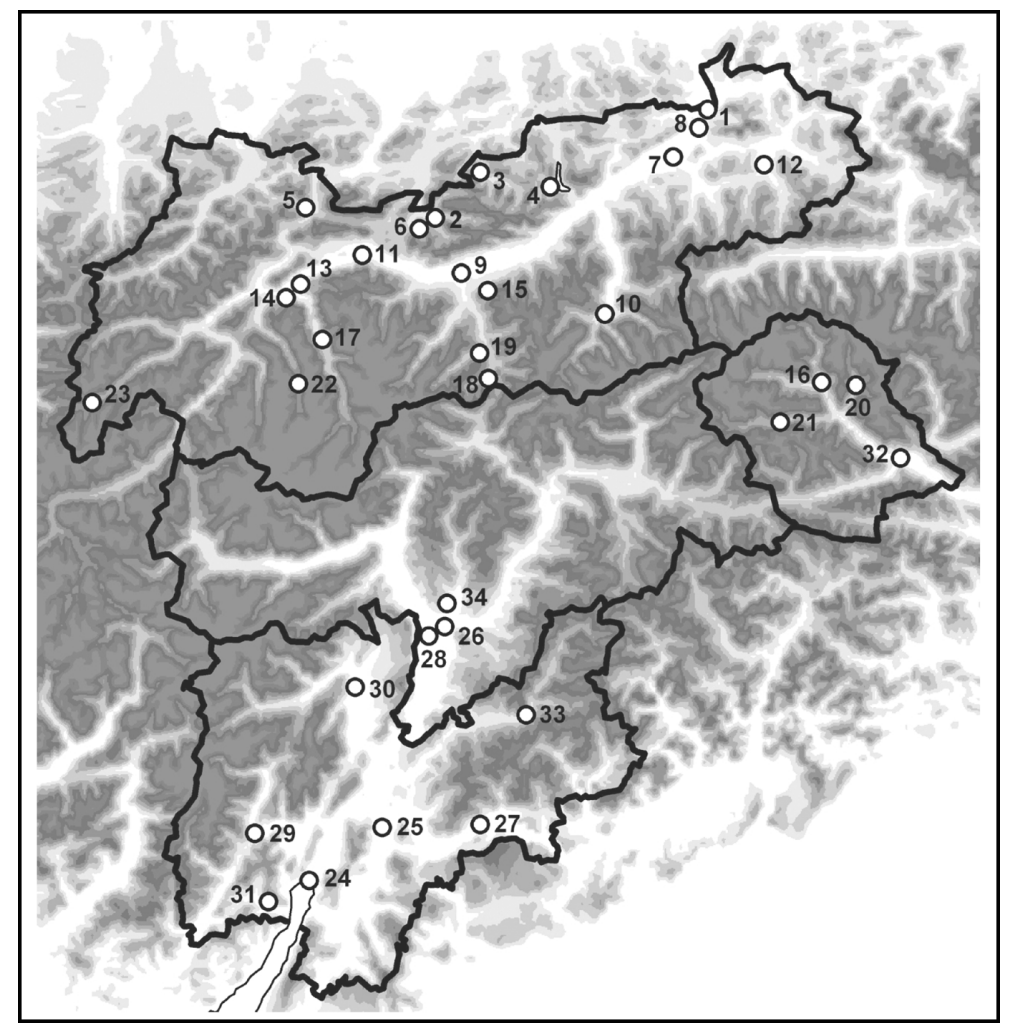

Fig. 4. Phenological stations for lilac flowering data. Numbers see Table 1. (Map showing topography: Dr. E. TASSER) 
Table 1. Onset of flowering dates of Syringa vulgaris at different altitudes in locations within Tyrol and Trentino. Data taken from (a) Phenological Observation Service for Tyrol; (b) DALla FIOR [4]; (c) DALla FiOR [5]; (d) DALla TORRE in FICKER [8]; (e) J. KERER, pers. comm.; (f) KoCH [13]; (g) KöCK and TRenKWAlder [14]; (h) Minio [23]; (i) PfaFf [25]; (k) Roller [27]; (l) own data

\begin{tabular}{|c|c|c|c|c|c|c|}
\hline & Location & $\begin{array}{l}\text { Altitude } \\
{[\mathrm{m}]}\end{array}$ & $\begin{array}{l}\text { Day of } \\
\text { year }[d]\end{array}$ & Date & $\begin{array}{l}\text { Phenological } \\
\text { observation }\end{array}$ & Ref. \\
\hline \multicolumn{7}{|c|}{ Northern Alps } \\
\hline 1 & Kufstein & 492 & 131 & May 11 & 1951-1999 & $\mathrm{f}$ \\
\hline 2 & Scharnitz & 964 & 155 & June 04 & 1951-1999 & $\mathrm{j}$ \\
\hline 3 & Hinterriß & 930 & 159 & June 08 & $1961-1973$ & $\mathrm{a}$ \\
\hline 4 & Pertisau & 933 & 152 & June 01 & $1961-1973$ & $\mathrm{a}$ \\
\hline 5 & Ehrwald & 1000 & 149 & May 29 & $1961-1973$ & $\mathrm{a}$ \\
\hline 6 & Leutasch & 1126 & 168 & June 17 & $1961-1973$ & a \\
\hline \multicolumn{7}{|c|}{ Central Alps and Inn Valley } \\
\hline 7 & Radfeld & 510 & 128 & May 08 & $1961-1973$ & $\mathrm{a}$ \\
\hline 8 & Kirchbichl & 550 & 136 & May 16 & $1961-1973$ & $\mathrm{a}$ \\
\hline 9 & Innsbruck & 580 & 124 & May 04 & $1889-1900$ & $\mathrm{~d}$ \\
\hline $9 a$ & Innsbruck & 579 & 116 & April 26 & 2003-2006 & 1 \\
\hline 10 & Zell am Ziller & 585 & 131 & May 11 & $1961-1973$ & a \\
\hline 11 & Telfs & 634 & 129 & May 09 & 1951-1999 & $\mathrm{f}$ \\
\hline 12 & Kitzbühel & 760 & 140 & May 20 & $1961-1973$ & $\mathrm{a}$ \\
\hline 13 & Zams & 772 & 134 & May 14 & $1961-1973$ & a \\
\hline 14 & Landeck & 818 & 126 & May 06 & $1946-1960$ & $\mathrm{k}$ \\
\hline $14 \mathrm{a}$ & Landeck & 825 & 138 & May 18 & 1961-1973 & a \\
\hline 15 & Rinn & 900 & 144 & May 24 & $1972-1988$ & $\mathrm{~g}$ \\
\hline 16 & Matrei in Osttirol & 975 & 146 & May 26 & 1951-1999 & $\mathrm{f}$ \\
\hline $16 \mathrm{a}$ & Matrei in Osttirol & 975 & 140 & May 20 & $1946-1960$ & $\mathrm{k}$ \\
\hline 17 & Umhausen & 1036 & 142 & May 22 & $1961-1973$ & a \\
\hline 18 & Brenner-Gries & 1157 & 160 & June 09 & 1951-1999 & $\mathrm{a}$ \\
\hline 19 & Trins & 1214 & 157 & June 06 & $1961-1973$ & $\mathrm{a}$ \\
\hline 20 & Kals am Großglockner & 1347 & 162 & June 11 & 1961-1966 & $\mathrm{a}$ \\
\hline $20 \mathrm{a}$ & Kals am Großglockner & 1347 & 153 & June 02 & 1995-2006 & $\mathrm{e}$ \\
\hline 21 & St. Jakob in Defereggen & 1389 & 156 & June 05 & $1946-1960$ & $\mathrm{k}$ \\
\hline 22 & St. Leonhard in Pitztal & 1371 & 167 & June 16 & $1961-1973$ & $\mathrm{a}$ \\
\hline 23 & Galtür & 1583 & 173 & June 22 & $1961-1973$ & a \\
\hline \multicolumn{7}{|c|}{ Southern Alps } \\
\hline 24 & Arco & 91 & 100 & April 10 & 1995-2004 & 1 \\
\hline 25 & Trento & 210 & 106 & April 16 & $1922-1951$ & $\mathrm{~b}$ \\
\hline 26 & Bozen & 254 & 107 & April 17 & $1915-1943$ & $\mathrm{~b}$ \\
\hline 27 & Borgo Val Sugana & 384 & 110 & April 20 & 1922-1961 & c \\
\hline 28 & Eppan & 400 & 114 & April 24 & 1922-1941 & $\mathrm{b}$ \\
\hline 29 & Tione Giudicarie & 565 & 123 & May 03 & 1922-1961 & $\mathrm{c}$ \\
\hline 30 & Cles & 658 & 130 & May 10 & 1922-1951 & $\mathrm{h}$ \\
\hline 31 & Pieve di Ledro & 659 & 128 & May 08 & 1922-1961 & $\mathrm{c}$ \\
\hline 32 & Lienz & 666 & 122 & May 02 & 1946-1960 & $\mathrm{k}$ \\
\hline 33 & Pedrazzo & 1104 & 134 & May 14 & $1922-1951$ & $\mathrm{~b}$ \\
\hline 34 & Oberbozen & 1200 & 143 & May 23 & 1916-1918 & $\mathrm{i}$ \\
\hline
\end{tabular}




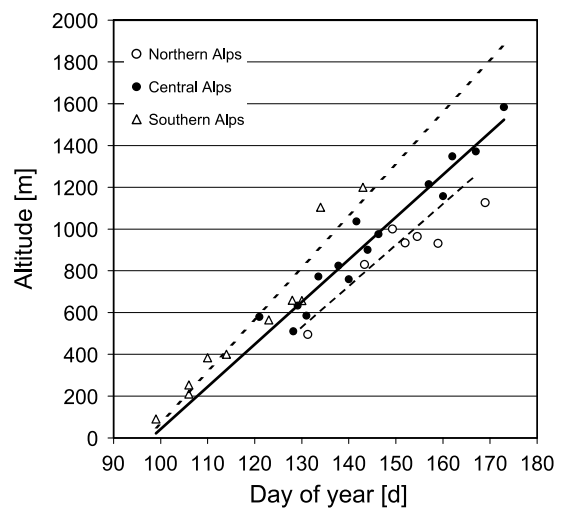

Fig. 5. Changes in flowering times (day of year) of Syringa vulgaris with increasing altitude along the north-south-transect. Circles: Northern Alps. Dots: Inn valley and valleys of the Central Alps. Triangles: Southern Alps

of temperature. Northern mountain ranges are cooler and rich in precipitation due to the Atlantic influence whereas inner alpine areas and mountain masses like the Central Alps are warmer. The locations in the Southern Alps are drier and warmer in spring (FLIRI [9], KUHN [15]). There is a close correlation between the flowering dates of all the sites in the north-south-transect and the mean temperature of the representative spring month April (Fig. 6). All in all a reduction in temperature of $1{ }^{\circ} \mathrm{C}$ postpones the onset of flowering by 6.6 days.

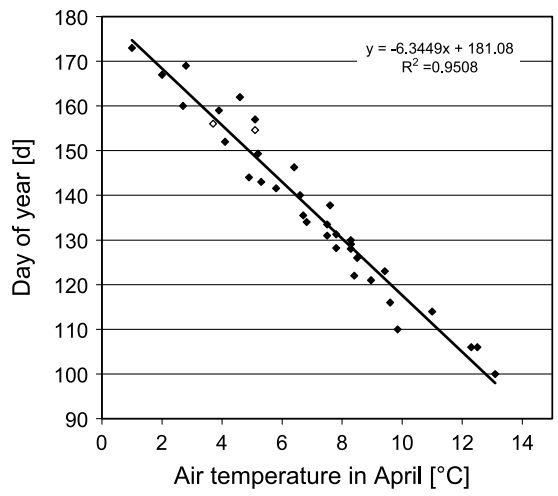

Fig. 6. Correlation between onset of flowering dates at all locations and mean temperatures in April. The relationship is highly significant $(r=-0.975 ; p<0.001$;

PEARSON) 


\subsection{Threshold Temperatures for Onset of Lilac Flowering}

Bud break and onset of flowering are only possible if temperatures regularly and consistently pass a specific threshold temperature. In 2005 in Innsbruck, daily means during linear elongation growth were $10 \pm 2^{\circ} \mathrm{C}$. During peak flowering they were $10-15^{\circ} \mathrm{C}$ with minimum daily means never below $5^{\circ} \mathrm{C}$ (see Fig. 3).

When looking for any correlation between phenological dates and temperature, the mean temperature of a 30-day period before the onset of the given phase (LAUSCHER and SCHNELLE [19]) is an easy option. The month before the onset of a certain phase best demonstrates the relationship between phenological dates and temperature.

To reveal relationships between the onset of flowering dates of lilac and site temperatures, daily means of the preceding 30 days must be known. In most cases daily temperatures were not available, therefore mean temperatures of the 30 days preceding flowering were calculated as follows: for onset of flowering at the beginning of a month (e.g. May), the monthly mean of the previous month (e.g. April) was taken; when flowering started in the middle of a month, the mean temperature of the flowering month $\left(T_{\mathrm{FM}}\right)$ and that of the previous month $\left(T_{\mathrm{PM}}\right)$ were summed and divided by 2 ; when flowering started 10 days into a month, the mean temperature $(\mathrm{Tm})$ was calculated by the formula $T m=\left(1 * T_{\mathrm{FM}}+2 * T_{\mathrm{PM}}\right) / 3$, when flowering started 20 days into the month the formula $\mathrm{Tm}=\left(1 * T_{\mathrm{PM}}+2 * T_{\mathrm{FM}}\right) /$ 3 was used.

In the Alps clear relationships could be shown between the onset of lilac flowering and the monthly means of the previous month (Table 2). LAUSCHER and SCHNELLE [19] used long-term phenological data sets to calculate a mean temperatures for the 30 days before the onset of flowering of $9.4^{\circ} \mathrm{C}$ for Paris and of $10.3^{\circ} \mathrm{C}$ for St. Petersburg. This leads to the conclusion that the threshold temperature is about $9-10^{\circ} \mathrm{C}$.

Table 2. Average threshold temperatures and deviations $\left({ }^{\circ} \mathrm{C}\right)$ of the month before the onset of lilac flowering in the Tyrolean Alps and Trentino Alps

\begin{tabular}{llllll}
\hline Region in the Alps & Mean & Median & SD & Max & Min \\
\hline Northern Alps & 9.7 & 9.7 & 0.83 & 10.8 & 8.6 \\
Central Alps and Inn valley & 9.6 & 9.6 & 0.79 & 10.9 & 8.3 \\
Southern Alps & 9.7 & 9.8 & 0.69 & 10.6 & 8.4 \\
\hline
\end{tabular}




\section{Discussion}

\subsection{Temperature Requirements for the Flowering of Lilac}

Successful development from flower bud initiation to unfolding of inflorescences depends on induction by environmental signals like temperature and photoperiod. For flowering process lilac requires the following temperature conditions: Towards the end of the previous year the buds have to be exposed to some weeks with temperatures below $6-8^{\circ} \mathrm{C}$ (chilling requirement). For bud break the temperature threshold of $9-10^{\circ} \mathrm{C}$ should be passed in March or April in the following year. Seasonal changes in insolation and changed photoperiod may interact with the temperatures.

Syringa vulgaris originally comes from Southeast Europe and therefore is favoured by temperatures in warmer and more temperate climates. On the Greek island Samos (Marathonkampos, $37^{\circ} 40^{\prime} \mathrm{N}$, $300 \mathrm{~m}$ a.s.l.) some shrubs of lilac, which must have started flowering about a week before, were observed to be at the peak of flowering on April 18, 2005 (day of year about 100; CH. KÖRNER, pers. comm.). In this region the daily mean temperatures range from $8-12^{\circ} \mathrm{C}$ in winter (November, December, January) with a daily minimum between 3 and $8^{\circ} \mathrm{C}$. During spring (March and April) means of $12-14^{\circ} \mathrm{C}$ were recorded. In Rome $\left(41^{\circ} 53^{\prime} \mathrm{N}, 51 \mathrm{~m}\right.$ a.s.l.; mean temperatures in March are $11.5^{\circ} \mathrm{C}$ and in April $14.4^{\circ} \mathrm{C}$ ) lilac starts flowering around April 11 (day of year 101). In Arco at Lake Garda the average onset of flowering also takes place around April 10 (average day of year 100). Long-term data sets show that in Arco daily temperature minima below $5^{\circ} \mathrm{C}$ occur regularly between November and January. As early as March (monthly mean: $9.7^{\circ} \mathrm{C}$ ) daily means are consistently above $10^{\circ} \mathrm{C}$ in Arco. These optimal growing conditions lead to the early onset of flowering of lilac.

Unfavourable conditions like cooler temperatures and longer snow cover at higher altitudes delay phenological dates. The onset of flowering is postponed due to later bud break and longer elongation growth. The collective data for Austria before the middle of the 20th century generally shows an altitudinal gradient of flowering dates from 3.1 to 4.7 days per $100 \mathrm{~m}$ (ROSENKRANZ [29]). For the period from 1961 to 1977 the means for the onset of flowering dates give an altitudinal gradient of 3.6 day $/ 100 \mathrm{~m}$ between 100 and $1400 \mathrm{~m}$ a.s.l. (ROLLER [28]). During extremely warm years development happens much quicker in the mountains than in the valley resulting in a lower gradient of 2-2.5 day/100 m (KoCH [11, 12]). 
Lilac cannot flower after either too mild a winter or insufficient warmth in spring. If temperatures remain below the threshold of $10^{\circ} \mathrm{C}$, reproductive growth will be suppressed. Too short a growing season could hinder the differentiation of next year's buds. In the Alps lilac can be planted up to an altitude of 1500-1600 $\mathrm{m}$ a.s.l. where it flowers between the middle of June and the beginning of July (day of year $165-180)$ with daily means of $10-12^{\circ} \mathrm{C}$. Towards the Pole (e.g. in Norway) lilac is planted up until $60^{\circ} \mathrm{N}$ (LAUSCHER [18]). These shrubs also start flowering at temperatures of $9.7-11.7^{\circ} \mathrm{C}$ between the beginning and middle of June (day of year 140-160). Where these temperatures are not reached successful planting cannot be expected.

In climate zones with warm winters the chilling requirements of Syringa vulgaris (of below $8^{\circ} \mathrm{C}$ ) cannot be fulfilled and therefore primary flowering induction cannot take place. In a Tenerife garden (Los Rodeos, $28^{\circ} 28^{\prime} \mathrm{N}$; about $600 \mathrm{~m}$ a.s.l.) shrubs of lilac were planted but over a period of several years they have not flowered (M. S. JIMÉNES and D. MORALES, pers. comm.). At this site the coldest monthly mean is measured at $12.4^{\circ} \mathrm{C}$ and the minimum monthly mean at $9.2^{\circ} \mathrm{C}$ in February (from between 1944-1989, Instituto Nacional de Meteorologia, Centro Zonal de Santa Cruz). During winter permanent temperatures below $10^{\circ} \mathrm{C}$ hardly occur and thus lilacs only grow in their vegetative form. It is remarkable that among the 378 sites in North America and Eurasia mentioned in the publication of SCHWARTZ et al. [32] there are no phenological observations of Syringa south of $30^{\circ}$ latitude.

\subsection{Variation in Onset of Flowering Dates Due to Climate Changes}

Analyses of phenological data from the European International Phenological Gardens between the years 1959 and 1996 showed that a temperature rise by 1 degree centigrade results in leafing 6.3 days earlier (MENZEL [21]). Phenological phase displacements of -7 days due to a 1 degree centigrade rise in spring temperature were discovered for different trees and shrubs by CHMIELEWSKI and RÖTZER [2].

It would be informative to know the flowering dates of lilac in different regions in relation to climate change. The present survey however does not suffice for analysis, as there were too few sites and little continuous data. However, two locations north and south of the Alps, namely Kufstein and Matrei in Osttirol, were chosen 
Table 3. Range of flowering dates of lilac from 1951 to 2000 in Kufstein and Matrei in Osttirol

\begin{tabular}{lllll}
\hline Location & Years & Date & Day of Year & Periods \\
\hline Kufstein & $1951-1999$ & May 11 & 131 & mean \\
Kufstein & $1962-1973$ & May 24 & 144 & cooler \\
Kufstein & $1989-2000$ & May 01 & 121 & warmer \\
\hline Matrei in Osttirol & $1951-1999$ & May 26 & 146 & mean \\
Matrei in Osttirol & $1962-1973$ & June 06 & 157 & cooler \\
Matrei in Osttirol & $1989-2000$ & May 14 & 134 & warmer \\
\hline
\end{tabular}

for further analysis. From the middle of the last century onwards there were clear fluctuations between colder and warmer periods (see Fig. 1). When compared to the flowering dates of lilac from the long-term data series from 1951 to 1999 (КоCH [13]) the onset of flowering dates during a colder period (1962-1973) were late by 10 days in Kufstein and 11 days in Matrei; during warmer periods (1989-2000) the onset of flowering dates were 13 and 12 days earlier in the same locations (Table 3). A 3-week amplitude in onset of flowering dates can be detected in these regions within only one century.

On the southern rim of the Alps there are no remarkable phase displacements of the earliest flowering dates as the warmer temperatures for development and growth are always reached. During the early decades of the 20th century lilac started flowering in Bozen around the middle of April (day of year 105-107: PFAFF [25], DALLA FIOR [4]), which coincides precisely with observations in 2005. In Arco the average onset of flowering for lilac has not changed markedly over time although there have been variations due to weather anomalies especially frost and late winter drought (day of year median 99, percentile: $10 \%=92 ; 90 \%=110$ ). However, temperatures over this long period have been quite consistent. The rise in temperature in Arco between 1960 and 2000 was $0.8^{\circ} \mathrm{C}$, which means $0.2^{\circ} \mathrm{C}$ in 10 years (TISI et al. [33]). The average temperature rise in the Mediterranean region after 1960 was about $0.3^{\circ} \mathrm{C}$ per decade; north of the Alps the temperature rose by more than $0.7^{\circ} \mathrm{C}$ per decade (WALTHER et al. [34]). Based on this climate change data an earlier onset of flowering dates is not traceable for Syringa vulgaris growing on the rim of the Southern Alps. DefiLA and ClOT [6] did not find a tendency for earlier vegetation development in the region of the Rhone Valley and the southern side of the Alps. This is in contrast to the northern cantons of Switzerland. 
Can lilac be used as a phenological indicator for climate change? Partly, but only in regions where the development of the plants is limited.

\section{Acknowledgements}

I thank the following institutions and persons for the supply of climate dates: Institute of Meteorology and Geophysics of the University Innsbruck (Prof. Dr. EKKEHARD DREISEITL), Central Institute for Meteorology and Geodynamics, Regional Center for Tirol and Vorarlberg (Dr. KARL GABL), Hydrographic Office of the Tyrolean Government, Innsbruck (Ing. MARTIN NEUNER). Important phenological data come from the former Phenological Service for Tyrol and from a project in collaboration with the Natural History Museum in Trento. I am very grateful to the numerous observers for collecting phenological data in the field.

\section{References}

[1] Borchert, R., Robertson, K., SchWARTZ, M. D., Williams-Linera, G. (2005) Phenology of temperate trees in tropical climates. Int. J. Biometeorol. 50: 57-65

[2] Chmielewski, F. M., Rötzer, TH. (2001) Response of tree phenology to climatic change across Europe. Agric. For. Meteorol. 108: 1001-1112

[3] Dalla FioR, G. (1933) Un decennio di osservazioni fitofenologiche a Trento con riferimenti a quelle di altre stazioni della Venezia Tridentina. Ann. Istituto tecnico "Leonardo da Vinci" di Trento 1933: 7-19

[4] DAlla FioR, G. (1951) Un terzo decennio di osservazioni fitofenologiche a Trento e risultati di analoghe osservazioni compiute in altre stazioni del Trentino-Alto Adige. Studi trentini di Scienze Naturali A28: 3-32

[5] DALla FIOR, G. (1963) Un quarto decennio di osservazioni fitofenologiche a Trento ed un secondo a Tione e a Pieve di Ledro, nonché osservazioni quinquennali, rispettivamente quadriennali, di un secondo decennio a Borgo e a Condino. Studi trentini di Scienze Naturali A40: 176-191

[6] Defila, C., Clot, B. (2001) Phytophenological trends in Switzerland. Int. J. Biometeorol. 45: 203-207

[7] Deutscher Wetterdienst: Buttler, K. P., Schmid, W. (eds.) (1991) Anleitung für die phänologischen Beobachter des Deutschen Wetterdienstes, 3. Aufl. Deutscher Wetterdienst, Offenbach am Main

[8] FICKER, H. VON (1909) Klimatographie von Österreich IV: Klimatographie von Tirol und Vorarlberg (mit Zoo- und Phytobiologischen Beiträgen von K. W. v. DALla TORRE), pp. 1-162. K.K. Zentralanstalt f. Meteorologie u. Geodynamik, Wien

[9] FLIRI, F. (1975) Das Klima der Alpen im Raume von Tirol. Wagner, Innsbruck

[10] IHNE, E. (1905) Phänologische Karte des Frühlingseinzugs in Mitteleuropa. Petermanns Geogr. Mitt. 5: 97-108

[11] KocH, E. (1993) Phänologische Jahresübersicht für Österreich im Jahr 1993. Wetter und Leben 45: 91-93

[12] KосH, E. (1994) Phänologische Jahresübersicht für Österreich im Jahr 1994. Wetter und Leben 46: 237-240

[13] KoCH, E. (2002) Phänologie Österreichs. In: Harlfinger, O., KoCH, E., SCHEIFINGER, H. (Hrsg.) Klimahandbuch der österreichischen Bodenschätze. 
Klimatographie, Teil 2: Strahlung, Weinbau, Phänologie, pp. 156-242. Wagner, Innsbruck

[14] KöcK, L., TREnKwalder, K. (1989) Witterungsverlauf, dargestellt in meteorologischen und phänologischen Tabellen mit Angaben von Mittel- und Extremwerten in Dekaden und 30jährigen Durchschnittswerten des Beobachtungszeitraumes 1951-1980. In: KöcK, L., Holaus, K. (eds.) 50 Jahre Landesanstalt für Pflanzenzucht und Samenprüfung in Rinn, pp. 197-210. Private edition, Innsbruck

[15] KuHN, M. (1997) Meteorologische und klimatische Bedingungen für die Flora von Nordtirol, Osttirol und Vorarlberg. In: POLATSCHEK, A. (eds.) Flora von Nordtirol, Osttirol und Vorarlberg. 1. Band, pp. 26-42. Tiroler Landesmuseum Ferdinandeum, Innsbruck

[16] LARCHER, W. (1978) Klima und Pflanzenleben in Arco. T.E.M.I., Trento

[17] LAUSCHER, F. (1978) Neue Analyse ältester und neuerer phänologischer Reihen. Arch. Met. Geoph. Biokl. B26: 373-385

[18] LAUSCHER, F. (1991) Durchschnittstemperaturen beim Eintritt phänologischer Phasen in Norwegen (self-published)

[19] LAUSCHER, F., SCHNELlE, F. (1986) Beiträge zur Phänologie Europas. V. Lange phänologische Reihen Europas und ihre Beziehungen zur Temperatur. Ber. Dtsch. Wetterdienst No. 169: 1-24

[20] Marcello, A. (1957) Il tempo e la stagione in fenologia. Nuovo Giornale Botanico Italiano 66: 929-1034

[21] MenZEL, A. (2000) Trends in phenological phases in Europe between 1951 and 1996. Int. J. Biometeorol. 44: 76-81

[22] MenZel, A., FABIAN, P. (1999) Growing season extended in Europe. Nature 397: 659

[23] Minio, M. (1937) Le osservazioni fitofenologiche della Rete Italiana nel 1935. Nuovo Giornale Botanico Italiano 44: 552-567

[24] MolisCH, H. (1930) Physiologie als Theorie der Gärtnerei, 6. Aufl. G. Fischer, Jena

[25] PfAFF, W. (1920) IV. Über den Einfluss der Höhenlage auf den Eintritt der Vegetationsphasen. Phaenologische Mitteilungen (Hessen) 26: 1-8

[26] ReITER, E. R. (1958) Klima von Innsbruck 1931-1955. Statistisches Amt, Innsbruck

[27] ROLLER, M. (1963) Durchschnittswerte phänologischer Phasen aus dem Zeitraum 1946 bis 1960 für 103 Orte Österreichs. Wetter und Leben 15: 1-12

[28] RolleR, M. (1978) Neue Normalwerte der Höhenabhängigkeit phänologischer Phasen in den Ostalpen. Jb. Zentralanstalt für Meteorologie und Geodynamik Wien, Anh. 6: 57-69

[29] Rosenkranz, F. (1951) Grundzüge der Phänologie. Fromme, Wien

[30] SCHNELlE, F. (1955) Pflanzenphänologie. Akad. Verlagsgesellschaft, Leipzig

[31] SCHÜEPP, W. (1950) Phänometrisches Experiment über die „Winterruhe“ einiger Pflanzen. Wetter und Leben 2: 205-211

[32] Schwartz, M. D., Ahas, R., AASA, A. (2006) Onset of spring starting earlier across the Northern Hemisphere. Global Change Biology 12: 343-361

[33] TISI, F., BRESCIANI, I., LARCHER, W. (2005) Monitoraggio fenologico in un parco di acclimatazione nell' Alto Garda. Informatore Botanico Italiano 37(1B): 686-687

[34] Walther, G.-R., Post, E., Convey, P., Menzel, A., Parmesan, C., Beebee, T. J. C., Fromentin, J.-M., Hoegh-Guldberg, O., Bairlein, F. (2002) Ecological responses to recent climate change. Nature 416: 389-394 


\section{Internet:}

Istituto Agrario di San Michele all'Adige: www.ismaa.it

Hydrographisches Amt, Provinz Bozen: www.provinz.bz.it/wetter

Zentralanstalt für Meteorologie und Geodynamik: www.zamg.ac.at

Author's address: em. Prof. Dr. Dr. h.c. Walter Larcher, Institut für Botanik, Sternwartestrasse 15, 6020 Innsbruck, Austria. E-Mail: walter.larcher@uibk.ac.at. 